\title{
Long-term effect of Tylenchulus semipenetrans on citrus tree quality in reclaimed land of Egypt
}

\author{
Abd-Elgawad, M.M.M., F.F.H. Koura*, S.A. Montasser**, M.M.A. Hammam*, and \\ Ahmed El-bahrawy*** \\ * Phytopathology Department, National Research Center, El-Tahrir St., Dokki 12622, Giza, Egypt, \\ ** Department of Agricultural Zoology and Nematology, Faculty of Agriculture, Al-Azhar University, Egypt, \\ *** Institute for Sustainable Plant Protection, National Council of Research, Bari, Italy.
}

\begin{abstract}
Citrus fruit yield is considered a short-term response to the citrus nematode, Tylenchulus semipenetrans damage and therefore this study addressed parameters measuring overall appearance of the sampled trees. Soil and roots from 20 trees in each of three mature: 'banzaheer' lemon, 'Baladi' mandarin, and 'Navel' orange and one immature: 'Navel' orange orchards, all grafted on sour orange rootstock, in Egypt were sampled for the citrus nematode, T. semipenetrans, in February 2011 to investigate their correlations with tree parameters (tree height and vigor, canopy diameter, and trunk circumference) that reflect long-term nematode damage of the sampled trees. The correlation between pairs of these four parameters were always positive and generally with high significant levels. Each of the four parameters was not significantly correlated with fruit yield of the mature trees but each of tree height and vigor, and canopy diameter was correlated with fruit yield of the immature Navel orange. The relationships between pairs of these biotic parameters and $T$. semipenetrans population density in fibrous roots and soil were not consistent. Eleven edaphic factors in mandarin and mature orange orchards were measured and compared. Both soils were dominated by rough grainy particles of sand. Levels of potassium, calcium, phosphorus, ammonium and nitrate as well as soil solution $\mathrm{pH}$, organic matter content and electric conductivity in the soil samples were significantly $(P \leq 0.01)$ different between the mandarin and orange orchards. To achieve better economic revenue of citriculture, local tackling of $T$. semipenetrans problem in newly reclaimed areas of Egypt was discussed.
\end{abstract}

Key words: citrus, crop-loss assessment, Tylenchulus semipenetrans management, Egypt.

\section{Introduction}

Egypt has an outstanding position as a citrus producer country due to its high crop size and quality, early fruiting season, low production costs, and closeness of exportation markets (Sherif, 2006). Therefore, the socioeconomic importance of citrus in Egypt is apparent based on considerable local consumption of citrus as fresh fruit and juice as well as huge exportation. Citriculture alleviates the striking 
problem of unemployment since it absorbs a lot of labor and also many orchardsowning families join to work due to the frequently small orchard size in Egypt and labor-intensive nature of citriculture. So, there is a continuous expansion in citriculture to newly reclaimed areas of Egypt (Sherif, 2006; Anonymous, 2015). This also contributes to solve the present pressing problem of overpopulation by resettling people in such new areas. Yet, such an expansion via wide desert reclaimed land necessitates growing of citrus seedlings in light soils where the citrus nematode (Tylenchulus semipenetrans) is potential limiting factor to citrus growth and production (Duncan, 2005; Abd-Elgawad et al., 2010, 2016). Thus, citrus yield is threatened by the nematodes which invade the newly planted area via infected seedlings, organic fertilizers, plant materials, irrigation, and machinery (AbdElgawad and McSorley, 2009; Hammam, 2013). As the citrus seedlings age, the nematode populations develop and reproduce rapidly and consequently progressing increases in citrus yield loss occur. So, orchards incur heavy losses even at their early stages which require tackling the problem collectively and substantially by all stakeholders and from different angles; biologically, chemically, physically or any other dictated form of control (Abd-Elgawad and Askary, 2015).

Although several reports (Timmer and Davis, 1982; Philis, 1989; AbdElgawad, 1995; Korayem and Hassabo, 2005; Sorribas et al., 2008; AbdElgawad et al., 2016) have estimated citrus fruit loss by $T$. semipenetrans, the short-term response of fruit yield to nematode management may reflect only a portion of yield loss due to the pest. Citrus orchards are long-lived, and we are unaware of reports measuring the long-term effects of nematode parasitism on the size and quality of immature and mature trees in Egypt. Thus, yield responses to nematode management in mature trees may under-represent yield losses if trees are significantly smaller or otherwise debilitated by nematodes at the beginning of research trials (Duncan et al., 1995). Moreover, control of $T$. semipenetrans via fumigant and non-fumigant nematicides has produced highly variable responses in fruit yield (Duncan et al., 1995; Duncan, 2005; Sorribas et al., 2008). Duncan et al. (1995) speculated that the difficulty in measuring the effects of nematodes on the size and quality of mature citrus trees is due to the long period required to establish and conduct such experiments. From the time they are planted, citrus trees may not attain full size for 15-20 years.

In this study, four orchards were selected, based on their previous data indicating various levels of nematode infection (Abd-Elgawad et al., 2011, 2016), as representative of many other, relatively newly established, orchards in Egypt. In each grove, the correlations between pairs of four parameters measuring overall appearance of the sampled trees and $T$. semipenetrans population density in fibrous roots and soil were determined. Also reported are comparisons of eleven edaphic factors in the 'Navel' orange and 'Baladi' mandarin orchards. Nematode management strategy that should be used in such areas is discussed. 


\section{Materials and Methods}

In a previous study (Abd-Elgawad et al., 2016), soil and root samples were collected from four citrus groves planted with 'banzaheer' lemon (Citrus aurantifolia), 'Baladi' mandarin (C. reticulata), and 'Navel' orange (C. sinensis) trees, respectively, grafted on sour orange (C. aurantium) rootstock at El-Nubaria district, El-Behera governorate, Egypt (Table 1). The groves, owned by private sector, were within $20 \mathrm{~km}$ of one another. Their soils were originally desert sands which were recently reclaimed by leveling, and mulching virgin soil with fertile, but probably nematode-infested, silty soil from the Nile Valley, to improve the soil quality, before planting possible infested material (Abd-Elgawad and McSorley, 2009). The trees were flood, but if water not enough drip, irrigated, spaced $5 \times 5 \mathrm{~m}$ and agricultural practices were carried out as recommended by the national program for improving citrus production (El-Barkoki and Abou-Aziz, 1989). Weed control was always done by hand hoeing. Based on their positive samples for $T$. semipenetrans in October 2008 (Abd-Elgawad et al., 2011), the same 20 uniform, randomly selected trees were re-sampled in February 2011 at each grove to track the nematode infestation levels of the four orchards (Abd-Elgawad et al., 2016). Citrus nematode counts (or their transformed $\log _{10}$ ) were expressed as number of second-stage juveniles $\left(\mathrm{J}_{2}\right)$ and males/ $150 \mathrm{~cm}^{3}$ soil, or number of females per $1 \mathrm{gm}$ fresh weight of fibrous roots. Densities of $T$. semipenetrans females, $\mathrm{J}_{2}$, and males in each grove were reported elsewhere (Abd-Elgawad et al., 2016) but used herein for investigating their correlations with parameters simultaneously measuring overall appearance of the sampled trees. So, height, vigor, canopy diameter, and trunk circumference of the sampled trees were measured during 2011 sampling. Trees were subjectively rated on a scale $0-4$, depending on canopy density, to estimate tree vigor (Duncan et al., 1995). Computer Minitab program was used to find correlation coefficients and their statistical probability levels ( $P$-values) between pairs of the variables of $T$. semipenetrans counts in soil, roots/their transformed logarithms, tree height and vigor, canopy diameter, and trunk circumference. From the twenty samples in each of the mandarin and mature orange groves (AbdElgawad et al., 2016), the remained soil of 16 random soil samples were selected to measure eleven edaphic factors: soil texture (United States Department of Agriculture classification), soil moisture, soil solution $\mathrm{pH}(1: 2.5$, soil: water), electrical conductivity in $\mathrm{dS} / \mathrm{m}(1: 1)$, organic matter (\%), $\mathrm{Ca} \mathrm{CO}_{3}(\%)$, ammonium and nitrate $\left(\mathrm{NH}_{4}+\mathrm{NO}_{3}\right.$, as ppm), available potassium (K, as ppm), Calcium (Ca \%), Magnesium (Mg\%), and phosphorus ( $P$, as $\mathrm{ppm})$. These factors were also measured for the mature orange soil during sampling in 2008 (Abd-Elgawad et al., 2011) but not reported there. Soil samples were analyzed using the methods of USDA (1984) and classified according to Soil Survey Staff (2003) by Soil Research Department, NRC, Egypt and compared using Student's $t$-tests. 
Table (1): Data of the four citrus orchards with sour orange rootstock (El-Behera, Egypt).

\begin{tabular}{|c|c|c|c|c|}
\hline Location name & El-Nagah 1 & El-Nagah 2 & El-Emam Malek 1 & El-Emam Malek 2 \\
\hline $\begin{array}{l}\text { Soil texture } \\
\text { (sand: silt: clay) }\end{array}$ & 98.9: $0.7: 0.4$ & 90.1: $0.7: 0.2$ & 90.2: $0.4: 0.4$ & 90: $0.6: 0.4$ \\
\hline $\begin{array}{l}\text { Soil } \mathrm{pH} \\
(1: 2.5 \text { water })\end{array}$ & 7.35 & 7.66 & 7.5 & 7.4 \\
\hline Scion cultivar & 'Baladi' mandarin & 'Navel' orange & 'Navel' orange & 'banzaheer' lemon \\
\hline Tree pruning & Every other year & Every other year & No pruning & Every other year \\
\hline Tree age in 2011 & 18 yr (mature) & 20 yr (mature) & $8 \mathrm{yr}$ (immature) & $19 \mathrm{yr}$ (mature) \\
\hline Sampling dates & $\begin{array}{c}27 \text { Oct., } 2008 \text { \& } \\
14 \text { Feb., } 2011\end{array}$ & $\begin{array}{c}27 \text { Oct., } 2008 \text { \& } \\
14 \text { Feb., } 2011\end{array}$ & $\begin{array}{c}27 \text { Oct., } 2008 \text { \& } \\
14 \text { Feb., } 2011\end{array}$ & $\begin{array}{l}27 \text { Oct., } 2008 \text { \& } \\
14 \text { Feb., } 2011\end{array}$ \\
\hline Harvest of yield & $\begin{array}{c}\text { Jan., Feb. \& } \\
\text { March (2011). }\end{array}$ & $\begin{array}{c}\text { Dec. (2010) \& } \\
\text { Jan. (2011). }\end{array}$ & $\begin{array}{c}\text { Dec. }(2010) \& \\
\text { Jan. }(2011) .\end{array}$ & $\begin{array}{l}\text { July (2010) to } \\
\text { March (2011) }\end{array}$ \\
\hline
\end{tabular}

\section{Results}

The average population densities of $T$. semipenetrans in each of soil (nematode juveniles and males) and fibrous roots (nematode females) published elsewhere (Abd-Elgawad et al., 2016) were used herein to investigate their relationship with the parameters measuring size and overall appearance of the trees in each grove (Tables 2-6). These measured parameters that may reflect long-term nematode damage included trunk circumference (range 25-95 cm), canopy diameter (range 1.5-4.6 m), tree height (range 1.2-3.7 m), and vigor ratings (range 1-4) (Table 2). The correlation between pairs of these variables were always positive and generally with high significant levels (Tables 3-6). Such parameters were not significantly $(P \leq 0.05)$ correlated with nematode counts in soil or roots of the mature trees (Tables 3-5). With the exception of trunk circumference, the tested parameters were not significantly $(P \leq 0.05)$ correlated with nematode counts in soil and roots (Table 6). Each of the four parameters, measuring tree size and overall appearance, was not significantly $(P \leq 0.05)$ correlated with fruit yield of the mature trees but each of three parameters was correlated $(P \leq 0.05)$ with fruit yield of the immature Navel orange (Table 7). These included canopy diameter and tree height and vigor (correlation coefficients, $r$, were $0.449,0.541$ and 0.881 , respectively).

No differences $(P \leq 0.05)$ were detected between the two sampling times of October 2008 and February 2011 in mature orange soil, concerning organic matter, electric conductivity, available phosphorus and potassium, calcium carbonate, 
content of sand, clay or silt, soil texture, and ammonium nitrate (Table 8). A two-fold difference $(P \leq 0.01)$ was found in the available calcium $(1.22$ vs. $0.61 \%)$. The soil solution $\mathrm{pH}$ and available magnesium significantly $(\mathrm{P} \leq 0.01)$ differed between the two sampling dates of orange (Table 8 ). Both soils were dominated by rough grainy particles of sand. Levels of potassium, calcium, phosphorus, ammonium and nitrate as well as soil solution $\mathrm{pH}$, organic matter content and electric conductivity in the soil samples were significantly $(P \leq 0.01)$ different between the mandarin and orange orchards in 2011 (Table 8).

Table (2): Characters measuring size and overall appearance of trees in four citrus groves grafted on sour orange in El-Nubaria district, Egypt.

\begin{tabular}{lcccc}
\hline $\begin{array}{c}\text { Citrus scion } \\
\text { (age in years in 2011) }\end{array}$ & $\begin{array}{c}\text { Trunk } \\
\text { circumference (cm) }\end{array}$ & $\begin{array}{c}\text { Canopy } \\
\text { diameter }(\mathbf{c m})\end{array}$ & $\begin{array}{c}\text { Tree height } \\
\mathbf{( c m )}\end{array}$ & $\begin{array}{c}\text { Tree } \\
\text { vigor }\end{array}$ \\
\hline Navel (20) & $40-95$ & $200-390$ & $190-300$ & $1-4$ \\
Navel (8) & $25-40$ & $190-290$ & $120-220$ & $1-4$ \\
Banzaheer lemon (19) & $55-75$ & $300-460$ & $290-370$ & $2-4$ \\
Baladi mandarin (18) & $45-75$ & $150-350$ & $150-290$ & $1-4$ \\
\hline
\end{tabular}

Table (3): Matrix of values for correlation coefficient followed by probability level in each square for pairs of trunk circumference, canopy diameter, tree height, vigor, and Tylenchulus semipenetrans counts in soil (J2), roots (females), and nematode-count-transformed logarithms $\left(\log _{10} \mathrm{~J} 2\right.$ and $\log _{10}$ females) in mature sweet orange, Citrus sinensis cv. Navel grafted on sour orange.

\begin{tabular}{llllllll}
\hline Parameter & Trunk & Canopy & Height & Vigor & J2 & Females & Log $_{10}$ J2 \\
\hline Canopy & 0.626 & & & & & & \\
Height & 0.003 & & & & & & \\
& 0.737 & 0.671 & & & & & \\
Vigor & 0 & 0.001 & & & & & \\
& 0.683 & 0.517 & 0.650 & & & & \\
J2 & 0.001 & 0.02 & 0.002 & & & & \\
& -0.19 & -0.237 & -0.13 & -0.18 & & & \\
Females & -0.422 & 0.314 & 0.585 & 0.447 & & & \\
& -0.049 & 0.106 & 0.167 & 0.204 & 0.286 & & \\
Log $_{10}$ J2 & -0.836 & 0.657 & 0.48 & 0.388 & 0.221 & & \\
& 0.731 & -0.148 & -0.014 & -0.063 & 0.981 & 0.308 & \\
Log $_{10}$ females & -0.147 & -0.009 & 0.066 & 0.033 & 0.481 & 0.945 & 0.491 \\
& 0.536 & 0.970 & 0.783 & 0.891 & 0.032 & 0 & 0.028 \\
\hline
\end{tabular}


Table (4): Matrix of values for correlation coefficient followed by probability level in each square for pairs of trunk circumference, canopy diameter, tree height, vigor, and Tylenchulus semipenetrans counts in soil (J2), roots (females), and nematode-count-transformed logarithms ( $\log _{10} \quad \mathrm{~J} 2$ and $\log _{10}$ females) in mandarin cv. Baladi grafted on sour orange.

\begin{tabular}{llllllll}
\hline Parameter & Trunk & Canopy & Height & Vigor & J2 & Females & Log $_{10}$ J2 \\
\hline Canopy & 0.756 & & & & & & \\
& 0.000 & & & & & & \\
Height & 0.518 & 0.688 & & & & & \\
& 0.019 & 0.001 & & & & & \\
Vigor & 0.736 & 0.774 & 0.782 & & & & \\
& 0 & 0 & 0 & & & & \\
J2 & 0.025 & -0.006 & 0.284 & 0.087 & & & \\
& 0.918 & 0.980 & 0.226 & 0.714 & & & \\
Females & 0.115 & 0.099 & 0.354 & 0.067 & 0.765 & & \\
& 0.628 & 0.677 & 0.126 & 0.780 & 0 & & \\
Log $_{10} \mathrm{~J} 2$ & 0.038 & 0.010 & 0.321 & 0.074 & 0.972 & 0.791 & \\
& 0.873 & 0.968 & 0.168 & 0.757 & 0 & 0 & \\
Log $_{10}$ females & 0.091 & 0.091 & 0.315 & 0.004 & 0.728 & 0.988 & 0.757 \\
& 0.703 & 0.702 & 0.177 & 0.988 & 0 & 0 & 0 \\
\hline
\end{tabular}

Table (5): Matrix of values for correlation coefficient followed by probability level in each square for pairs of trunk circumference, canopy diameter, tree height, vigor, and Tylenchulus semipenetrans counts in soil (J2), roots (females), and nematode-count-transformed logarithms $\left(\log _{10} \mathrm{~J} 2\right.$ and $\log _{10}$ females) in C. aurantifolia cv. Banzaheer lemon grafted on sour orange.

\begin{tabular}{lcllllll}
\hline Parameter & Trunk & Canopy & Height & Vigor & J2 & Females & Log $_{10}$ J2 \\
\hline Canopy & 0.505 & & & & & & \\
Height & 0.023 & & & & & & \\
Vigor & 0.507 & 0.490 & & & & & \\
& 0.023 & 0.028 & & & & & \\
J2 & 0.268 & 0.505 & 0.777 & & & & \\
& 0.254 & 0.023 & 0 & & & & \\
Females & 0.343 & 0.311 & 0.260 & 0.084 & & & \\
& 0.138 & 0.182 & 0.269 & 0.724 & & & \\
Log10 J2 & 0.333 & 0.148 & 0.280 & 0.127 & 0.901 & & \\
& 0.151 & 0.534 & 0.232 & 0.593 & 0 & & \\
Log10 females & 0.411 & 0.428 & 0.271 & 0.268 & 0.897 & 0.871 & \\
& 0.072 & 0.060 & 0.247 & 0.254 & 0 & 0 & \\
\hline
\end{tabular}


Table (6): Matrix of values for correlation coefficient followed by probability level in each square for pairs of trunk circumference, canopy diameter, tree height, vigor, and T. semipenetrans counts in soil (j2), roots (females), and nematode-count-transformed logarithms $\left(\log _{10}\right.$ j2 and $\log _{10}$ females) in immature sweet orange, Citrus sinensis cv. Navel grafted on sour orange.

\begin{tabular}{|c|c|c|c|c|c|c|c|}
\hline Parameter & Trunk & Canopy & Height & Vigor & J2 & Females & $\log _{10} \mathrm{~J} 2$ \\
\hline Canopy & $\begin{array}{l}0.365 \\
0.113\end{array}$ & & & & & & \\
\hline Height & $\begin{array}{l}0.273 \\
0.245\end{array}$ & $\begin{array}{l}0.808 \\
0\end{array}$ & & & & & \\
\hline Vigor & $\begin{array}{l}0.198 \\
0.404\end{array}$ & $\begin{array}{l}0.576 \\
0.008\end{array}$ & $\begin{array}{l}0.768 \\
0\end{array}$ & & & & \\
\hline $\mathrm{J} 2$ & $\begin{array}{l}0.385 \\
0.093\end{array}$ & $\begin{array}{l}0.108 \\
0.651\end{array}$ & $\begin{array}{l}0.088 \\
0.713\end{array}$ & $\begin{array}{l}-0.087 \\
0.716\end{array}$ & & & \\
\hline Females & $\begin{array}{l}0.481 \\
0.032\end{array}$ & $\begin{array}{l}0.315 \\
0.176\end{array}$ & $\begin{array}{l}0.108 \\
0.651\end{array}$ & $\begin{array}{l}-0.051 \\
0.830\end{array}$ & $\begin{array}{l}0.656 \\
0.002\end{array}$ & & \\
\hline Log10 J2 & $\begin{array}{l}0.431 \\
0.058\end{array}$ & $\begin{array}{l}0.092 \\
0.701\end{array}$ & $\begin{array}{l}0.064 \\
0.788\end{array}$ & $\begin{array}{l}-0.097 \\
0.683\end{array}$ & $\begin{array}{l}0.981 \\
0.000\end{array}$ & $\begin{array}{l}0.669 \\
0.001\end{array}$ & \\
\hline Log10 females & $\begin{array}{l}0.464 \\
0.039\end{array}$ & $\begin{array}{l}0.331 \\
0.155\end{array}$ & $\begin{array}{l}0.146 \\
0.540\end{array}$ & $\begin{array}{l}-0.004 \\
0.986\end{array}$ & $\begin{array}{l}0.620 \\
0.004\end{array}$ & $\begin{array}{l}0.992 \\
0\end{array}$ & $\begin{array}{l}0.641 \\
0.002\end{array}$ \\
\hline
\end{tabular}

\section{Discussion}

The citrus nematode $T$. semipenetrans was the most common plant-parasitic nematode in the examined orchards as occurs in other citrus-growing areas worldwide (Duncan, 2005; Abd-Elgawad et al., 2010). Average numbers of females per gram of fibrous roots in samples from lemon, mandarin and orange (20 and 8-year-old, equivalent to mature and immature orange) orchards were 286, 354, 445 and 69 but were 1279, 3326, 2967 and 210 for $\mathrm{J} 2$ and males $150 \mathrm{~cm}^{-3}$ soil, respectively (Abd-Elgawad et al., 2016). The nematode has been dispersed to new citrus areas mostly by seedlings with infected root and soil, followed by further local spread by unsanitary agricultural practices. These nematode data document previous surveys (e.g., Mokbel et al., 2006; Abd-Elgawad and McSorley, 2009; Bakr et al., 2011) and represent a typical paradigm of infested groves in newly reclaimed areas in Egypt. The nematode spread results mainly from the anthropogenic movement of citrus nematodes into newly planted soil through infected citrus seedlings and mulching virgin soil with infested soil from the Nile Valley (Lehman, 2004; Abd-Elgawad and McSorley, 2009). When left without control, the nematode multiplies over time to reach higher and more damaging levels as occurred in older nearby groves (e.g., Abd-Elgawad, 1992). Yet, the only way to ease the pressure on available water resources is to come out of the Nile valley and Delta to the vast horizons of the desert where the available natural resources can ensure the establishment of stable urban communities. 
Each of tree height and vigor, and canopy diameter measured herein was correlated with fruit yield of the immature Navel orange. Such biotic variables are logically affected by the pest albeit unstudied factors interact with the citrus tree and influence the outcomes of the trials. Therefore, prompt measures to apply the citrus nursery certification program in Egypt have recently been emphasized (AbdElgawad et al., 2016). This program requires that non-infested orchards be protected from the introduction of these nematodes from contaminated sources or infested orchards (Inserra et al., 2005). Other implicated issues such as sampling to certify a site/plant material to be free of citrus nematode, other diseases and species identification (Salama and Abd-Elgawad, 2003; Inserra et al., 2005; AbdElgawad et al., 2010) should be considered. The ministry of agriculture should tackle the problem by allocating more funds for sufficient production of certified seedlings, increase number extension personnel knowledgeable enough to advice, assist and guide citrus growers for best nematode management approach, and finally legislating a law to prevent the use of non-certified citrus seedlings. Also, local devices may be used to protect non-infested orchards from the nematode introduction. For example, quicklime, calcium oxide, may be used as quite available and cheap material for the disinfestation; i.e. to clean equipment from soil and root debris before moving between groves to prevent the nematode spread. Nematodecontaminated manure or organic matter should not be added to the soil. Good potassium fertilization and soaking pigeon droppings manure in ferrous sulfate and ammonium sulfate solution before pumping into the irrigation network could suppress phytonematodes in citrus orchards (unpublished data). The limiting factor (Thomason and Caswell, 1987) should be considered. This may include any factor which could generally confound, hide, lessen or otherwise aggravate nematode effect on tree vigor and fruit yield.

The inconsistent relationships between $T$. semipenetrans population densities and biotic parameters measuring size and overall appearance of the citrus trees reported here (Tables 2-5) and elsewhere (e.g., Duncan et al., 1995; Duncan, 2005; Sorribas et al., 2008; Abd-Elgawad et al., 2011) may result from one or more of such factors as inadequate pruning, irrigation, fertilization, and/or pest/pathogen management. For example, the available potassium, phosphorus, and nitrogen in the tested groves (Table 8) are sometimes less than or near the nutrient threshold level which is $250 \mathrm{ppm}, 10 \mathrm{ppm}$ and $40 \mathrm{ppm}$, respectively (Tisdale et al., 1985). Apparently, nutrients tend to drain away with the water in both orange and mandarin sand soils and therefore they were generally nutrientpoor. Therefore, adequate fertilization program should be implemented to attain sufficient and balanced nutrition and optimize size and quality of citrus yield in such orchards. Fertilization choices are better guided by soil analysis, and complemented by foliar diagnosis. Egypt is a case in point but such approaches to tackle the nematode problems of citrus apply generally to many developing countries. Although resistant rootstocks to manage $T$. semipenetrans are also available, their 
conscious use, if applicable, should be followed since they mostly do not adapt to Egyptian conditions especially soil $\mathrm{pH}$. We suggest also a tactic based on a snapshot of $T$. semipenetrans sampling and control to mitigate the nematode problem before worsening.

Table (7): Correlation coefficient ( $r$ ) followed by probability level $(P)$ of linear relation between parameters reflecting long-term nematode damage and the subsequent citrus yield $\left(\mathrm{kg} \mathrm{tree}^{-1}\right)$ in each of four Egyptian orchards at newly reclaimed land $(n=20)$.

\begin{tabular}{lcccccccc}
\hline \multirow{2}{*}{ Scion/orchard } & \multicolumn{4}{c}{ Tree parameters reflecting long-term nematode damage } \\
\cline { 2 - 9 } & \multicolumn{2}{c}{ Trunk } & \multicolumn{2}{c}{$\begin{array}{c}\text { Canopy } \\
\text { diameter }\end{array}$} & \multicolumn{2}{c}{ Tree height } & \multicolumn{2}{c}{ Tree vigor } \\
\cline { 2 - 10 } & $\mathbf{r}$ & $\mathbf{P}$ & $\mathbf{r}$ & $\mathbf{P}$ & $\mathbf{r}$ & $\mathbf{P}$ & $\mathbf{r}$ & $\mathbf{P}$ \\
\hline Banzaheer lemon & -0.130 & 0.585 & -0.313 & 0.178 & 0.141 & 0.552 & 0.021 & 0.932 \\
Baladi mandarin & 0.122 & 0.609 & 0.162 & 0.495 & 0.096 & 0.686 & 0.175 & 0.460 \\
Mature Navel orange & 0.420 & 0.065 & 0.106 & 0.657 & 0.117 & 0.623 & 0.094 & 0.693 \\
Immature Navel orange & 0.065 & 0.786 & 0.449 & 0.047 & 0.541 & 0.014 & 0.881 & 0.0 \\
\hline
\end{tabular}

Table (8): Comparison of edaphic characteristics of 'Navel' orange and 'Baladi' mandarin orchard soils with trees favoring high and low relative standard errors of Tylenchulus semipenetrans population levels, respectively.

\begin{tabular}{lccc}
\hline \multicolumn{1}{c}{ Variable } & $\begin{array}{c}\text { Orange } \\
\text { (yr 2008) }\end{array}$ & $\begin{array}{c}\text { Orange } \\
\text { (yr 2011) }\end{array}$ & $\begin{array}{c}\text { Mandarin } \\
\text { (yr 2011) }\end{array}$ \\
\hline Soil pH (1:2.5 water) & $7.48^{*}$ & 7.66 & $7.35^{+}$ \\
Electric condu-ctivity (dS/m) & $0.36^{\text {n.s. }}$ & 0.26 & $0.56^{+}$ \\
Organic matter (\%) & $0.97^{\text {n.s. }}$ & 0.86 & $1.65^{+}$ \\
Calcium carbonate (\%) & $1.84^{\text {n.s. }}$ & 2.09 & $2.05^{\text {n.s. }}$ \\
Available Phosphorus (ppm) & $10.41^{\text {n.s. }}$ & 12.55 & $15.94^{+}$ \\
Available Potassium (ppm) & $247.6^{\text {n.s. }}$ & 186.4 & $643.7^{+}$ \\
Available Calcium (\%) & $1.22^{*}$ & 0.61 & $0.36^{+}$ \\
Available Magnesium (\%) & $0.28^{*}$ & 0.06 & $0.06^{\text {n.s. }}$ \\
Ammonium and Nitrate (ppm) & $27.4^{\text {n.s. }}$ & 24.75 & $83.7^{+}$ \\
Moisture (\%) & 9.4 & Not available & 5.0 \\
Very coarse sand (\%) & 36.2 & 40.5 & 37 \\
Coarse sand (\%) & 48.5 & 46.2 & 43.2 \\
Moderate sand (\%) & 1.1 & 0.3 & 0.6 \\
Fine sand (\%) & 9.3 & 8.1 & 11.9 \\
Very fine sand (\%) & 4.1 & 4.0 & 6.2 \\
Silt and clay (\%) & 0.8 & 0.9 & 1.1 \\
Soil texture (USDA) & Sandy & Sandy & Sandy \\
\hline
\end{tabular}

*, ${ }^{+}$Horizontal means different $(P \leq 0.01)$ between orange in 2008 and 2011 , and between orange 2011 and mandarin 2011, respectively (n.s. $=$ not significant at $P \leq 0.05)$. ( ${ }^{*}$ for difference between first and second column but ${ }^{+}$for difference between third and second column). Orange in 2011 was compared separately with each of orange 2008 and mandarin 2011 according to Student's $t$-test.

${ }^{z}$ United States Department of Agriculture (1984). 
Each of the four biotic parameters measuring size and overall appearance of the citrus trees (Table 2 ) was not significantly $(P \leq 0.05)$ correlated with numbers of nematodes associated with mature trees in soil or roots (Tables 3-5). These agree with Duncan et al. (1995)'s report which gave a good account of relating parameters of tree size and overall appearance to the nematodes. They recorded no differences in canopy diameter, tree height, and vigor between trees supporting high and low $T$. semipenetrans population levels. The present data partially corroborates (O'Bannon and Tarjan, 1973)'s records that trees planted in soil heavily infested with $T$. semipenetrans grow more slowly than trees in non-infested soil because our records for each of canopy diameter, tree height, and vigor was significantly correlated with yield, but, of immature trees only (Table 6). Their records do not support ours for mature trees (Tables 3-5). As a compromise, young trees (approximately 5-10 years old) tend to have greater growth rates in relation to their overall appearance (Wheaton et al., 1999) than old ones and consequently biotic and abiotic factors may have more impact on young than old trees. Therefore, it is likely that variables that reflect long-term damage, i.e. trunk circumference, canopy diameter, tree height, and vigor ratings, are more adversely affected by the nematodes in immature than mature trees. For mature trees, Duncan et al. (1995) speculated that yield was primarily correlated with tree organs subject to continuous renewal in terms of fruit yield, secondary roots and leaves rather than variables that reflect long-term damage. Moreover, depending on the extent of nematode damage such as $T$. semipenetrans induced potassium deficiency in the leaves, priority of vegetative over reproducing growth may have occurred. Other factors such as periodic pruning of the trees may reduce size differences between these parameters and disrupt their correlation with yield and/or nematode counts.

Our main objective of measuring some edaphic factors (Table 8) in the newly reclaimed areas is to better understand and characterize the nematode problem and help to find out the best solution. For example, the selected nematicide should be compatible with these sandy and alkaline soils. In this respect, the degradation of most post-plant applied nematicides is enhanced at soil pH $>7.0$ (Van Gundy and Martin, 1961). Also, nematicidal application via soil is not favored due to quick leaching in such sandy soil reported herein and because of the potential for groundwater contamination. Thus, the benefit to the tree resulting from foliar treatment with systemic oxamyl is likely more effective than soil treatment with cadusafos. Moreover, oxamyl price is less than half the price of cadusafos. Yet, we must take into account careful oxamyl use especially on high foliage so as not to hurt the eyes.

\section{Acknowledgment}

Thanks to M. I. Eltaweel and S. Elashree for their assistance in soil analysis. This research work was supported in part by the In-house project No. 10120604 and US-Egypt Science and Technology Joint Fund (project No. 172). 


\section{References}

Abd-Elgawad, M.M. (1992). Spatial distribution of the phytonematode community in Egyptian citrus groves. Revue De Nematologie 14, 367-373.

Abd-Elgawad, M.M. (1995). Estimate of (Naval) orange yield loss in Tylenchulus semipenetrans-infested groves. Egyptian Journal of Applied Science 10, 614.

Abd-Elgawad, M.M.M. and McSorley, R. (2009). Movement of citrus nematodeinfested material onto virgin land: detection, current status and solutions with cost-benefit analysis for Egypt. Egyptian Journal of Agronematology $7(1), 35-48$.

Abd-Elgawad, M.M.M. and Askary, T.H. (2015). Impact of phytonematodes on agriculture economy. In: Askary, T.H. and Martinelli, P.R.P. (eds). Biocontrol Agents of Phytonematodes. Wallingford, CAB International, UK, pp. 3-49.

Abd-Elgawad, M.M.M., Al-Yahya, F.A. and Stephan, Z.A. (2010). Nematodes of citrus. In: Abu-Gharbieh, W.A., Al-Hazmi, A.S., Stephan, Z.A. \& Dawabah, A.A. (eds). Plant Nematodes in Arab Countries (in Arabic). Amman, Jordan, Darwael for publishing, Arab Society of Plant Protection, pp.553-602.

Abd-Elgawad, M.M.M., Duncan, L.W., Koura, F.H.F., Abd El-Wahab, A.E., Montasser, S.A. and Hammam, M.M.A. (2011). Management revision and observations on Tylenchulus semipenetrans on citrus yield in Egypt. Egyptian Journal of Agronematology 10(1), 64-77.

Abd-Elgawad, M.M.M., Faika F. H. Koura, S. A. Montasser and M.M.A. Hammam (2016). Distribution and losses of Tylenchulus semipenetrans in citrus orchards on reclaimed land in Egypt. Nematology 26(10): In press.

Anonymous (2015). Area, productivity and production of horticultural crops for year 2015 (in Arabic). Egyptian Economic Affairs Sector, Ministry of Agriculture, Giza, Egypt.

Bakr, R.A., Mahdy, M.E. and Mousa, E.M. (2011). A survey of root-knot and citrus nematodes in some new reclaimed lands in Egypt. Pakistan Journal of Nematology 29(2), 165-170.

Duncan, L.W. (2005). Nematode parasites of citrus. In: Luc, M., Sikora, R.A. and Bridge, J. (Eds). Plant Parasitic Nematodes in Subtropical and Tropical Agriculture, $2^{\text {nd }}$ edition. Wallingford, U.K., CABI Publishing, pp. 437-466.

Duncan, L.W., Mashela, P., Ferguson, J. Graham, J., Abou-Setta, M.M. and EIMorshedy, M.M. (1995). Estimating crop loss in orchards with patches of mature citrus trees infected by Tylenchulus semipenetrans. Nematropica 25, 43-51. 
El-Barkoki, M.H. and Abou-Aziz, A.B. (1989). The national program for improving citrus production (in Arabic). Academy of scientific Research and Technology, Ministry of Agriculture and the National Research Centre, Cairo, Egypt.

Hammam, M.M.A. (2013). Potential of some recent approaches for the control of phytonematodes on citrus. PhD thesis. Al-Azhar University, Cairo, Egypt, $302 \mathrm{pp}$.

Inserra, R.N., Stanley, J.D., O'Bannon J.H. and Esser, R.P. (2005). Nematode quarantine and certification programmes implemented in Florida. Nematologia Mediterranea 33, 113-123.

Korayem, A.M. and Hassabo, S.A.A. (2005). Citrus yield in relation to Tylenchulus semipanetrans in silty loam soil. International Journal of Nematology 15(2), 179-182.

Lehman, P.S. (2004). Cost-benefits of nematode management through regulatory programs. In: Chen, Z.X., Chen, S.Y., \& Dickson, D.W. (eds). Nematology Advances and Perspectives. Volume 2; Nematode Management and Utilization. Wallingford, U.K. CABI Publishing, pp. 1133-1177.

Mokbel, A.A., Ibrahim, I.K.A., EL-Saedy, M.A.M. and Hammad, S.E. (2006). Plant parasitic nematodes associated with some fruit trees and vegetable crops in Northern Egypt. Egyptian Journal of Phytopathology 34(2), 43-51.

O'Bannon and Tarjan, A. (1973). Preplant fumigation for citrus nematode control in Florida. Joumal of Nematology 5, 88-95.

Philis, J. (1989). Yield loss assessment caused by the citrus nematode Tylenchulus semipenetrans on Valencia oranges in Cyprus. Nematologia Mediterranea $17,5-6$.

Salama, H.S. and Abd-Elgawad, M.M.M. (2003). Quarantine problems: an analytical approach with special reference to palm weevils and phytonematodes. Archives of Phytopathology and Plant Protection 36, 4146.

Sherif, S.A.S. (2006). Citrus varieties available for citrus improving program (in Arabic). Horticulture Research Institute, Egyptian Ministry of Agriculture, Giza, Egypt.

Soil Survey Staff (2003). Key to soil taxonomy, USDA. NRCS, $8^{\text {th }}$ edition.

Sorribas, F.J., Verdejo-Lucas, S., Pastor, J., Ornat, C., Pons, J. and Valero, J. (2008). Population densities of Tylenchulus semipenetrans related to physicochemical properties of soil and yield of clementine mandarin in Spain. Plant Disease 92, 445-450. 
Thomason, I.J. and Caswell, E.P. (1987). Principles of nematode control. In: Brown, R.H. \& Kerry, B.R. (eds). Principles and practice of nematode control in crops. Melbourne, Australia, Academic Press, pp. 87-130.

Timmer, L.W. and Davis, R.M. (1982). Estimate of yield loss from the citrus nematode in Texas grapefruit. Journal of Nematology 14(4), 582-585.

Tisdale, S.L., Nelson, D.L. and Beton, J.D. (1985). Soil fertility and fertilizers $4^{\text {th }}$ Ed. New York, USA, Macmillan Publishing Company.

USDA (1984). Procedures for collecting soil samples of analysis for soil survey. USDA, Soil Conservation Service, Report No. 1, USA.

Van Gundy, S., and Martin, J.P. (1961). Influence of Tylenchulus semipenetrans on the growth and chemical composition of sweet orange seedlings in soils of various exchangeable cation ratios. Phytopathology 51, 146-151.

Wheaton, T.A., Castle, W.S., Whitney, J.D. and Tucker, D.P.H. (1999). Horticultural practices for citrus health. In: Timmer, L.W. \& Duncan, L.W. (Eds). Citrus Health Management., St. Paul, Minnesota, USA, APS Press. 


\section{الملخص العربي}

التأثير طويل المدي لنيماتودا تيلنكيولس سميبنترانس على صفات أشجار الموالح بالأراضي المستصلحة في مصر

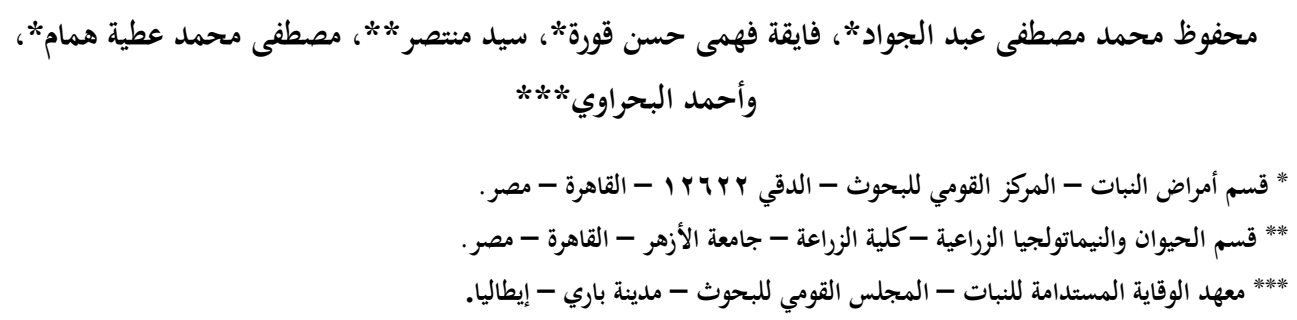

يعتبر الفقد في محصول ثمار أشجار الموالح المصابة بنيماتودا تيلنكيولس سميبنتانس

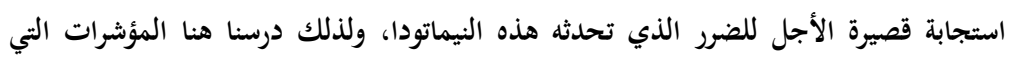

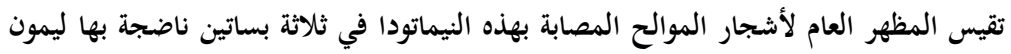

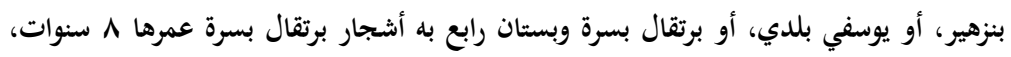

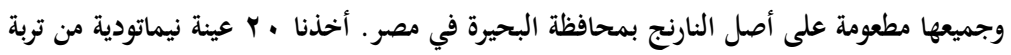

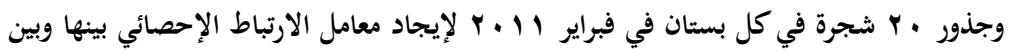

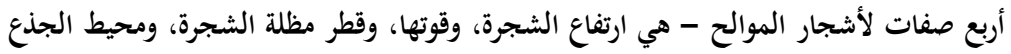

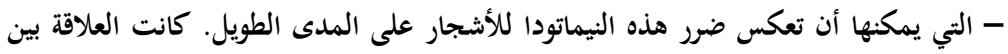

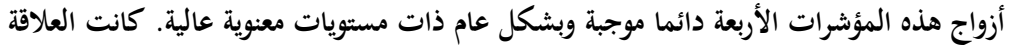

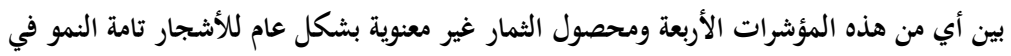
حين كانت علاقة كل من ارتفاع الشجرة، وقوتها، وقطر مظلة الشجرة بمحصول الثمار ذات

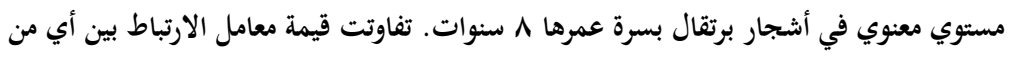

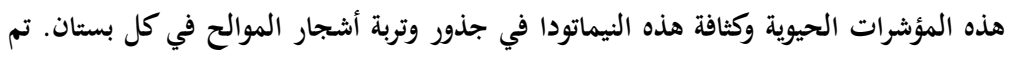

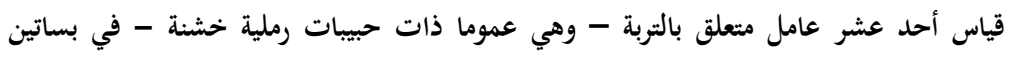
البرتقال تام النمو واليوسفي ومقارنتها. كانت مستويات البوتاسيوم والكالسيوم والفوسفور والأمونيوم والنترات وكذلك درجة حموضة التربة، ومحتواها من المادة العضوية ودرجة التوصيل

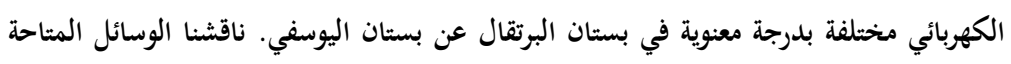

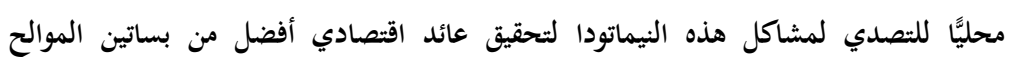
بالمناطق المستصلحة حديثا في مصر. 